\title{
MONETARY LIQUIDITY AND THE BUBBLES IN THE U.S. HOUSING MARKET
}

\author{
I-Chun TSAI ${ }^{a, *}$ \\ a Department of Finance, National University of Kaohsiung, No. 700, Kaohsiung University Rd., \\ Nanzih District, 811, Kaohsiung, Taiwan, R.O.C.
}

Received 24 April 2013; accepted 15 November 2013

\begin{abstract}
Extant studies indicate that the excessive easing of monetary supplies can result in surplus liquidity, which can consequently facilitate the formation of asset bubbles. This study references data on house prices in the U.S. from January 1991 to August 2012 to explore the correlations between monetary liquidity and house price bubbles in the U.S. housing market. Fluctuations in house prices are classified as related to either fundamentals (the mean reversion behavior and responses to information of the current period) or bubbles (self-related behavior). Results show a significant correlation between the formation of housing bubbles and monetary supplies. Long-term easing of monetary supplies can cause housing marketing returns to deviate from fundamentals, which then results in an increase in continuous fluctuations in house prices and the likelihood of the formation of house price bubbles.
\end{abstract}

KEYWORDS: Monetary liquidity; Housing bubbles; Monetary policy; Housing price index; The U.S. housing market

\section{INTRODUCTION}

Extant studies have indicated that loose monetary policies may be the primary cause of imbalance in the asset markets. Unlike previous studies, which have focused on the correlation between interest rates and house price bubbles (Shiller 2009; Yang et al. 2010; McDonald, Stokes 2013), this study discusses the correlation between monetary supplies and house price bubbles. This work investigates the liquidity effect caused by monetary policies on the behavior of house prices and analyzes further how surplus monetary supplies affect the formation of house price bubbles.

This study aims to document the correlation between monetary liquidity and house price bubbles using both theoretical and empirical model analyses. Determining whether money supply serves an important function in housing bubbles is crucial, which leads to the question of whether central banks should intervene in bubbles. Bernanke (2010) suggested that the best response to the housing bubble would have been regulatory, not

\footnotetext{
* Corresponding author. E-mail: ictsai@nuk.edu.tw
}

monetary ${ }^{1}$. However, if easing monetary policy is the main reason for the strong and non-fundamental house price rise, then the Fed should consider the influence of these policies on house prices to prevent it causes the housing bubble when implementing relevant monetary policies. Neglecting the influence of these policies may easily result in the emergence of a bubble or the collapse of the housing market.

Numerous studies have verified the correlation between monetary supplies and the behavior of house prices, including Iacoviello (2005), Mishkin (2007), and Taylor (2007). Other studies have used vector auto regression (VAR) models to verify the transmission effect that monetary policies have on house prices, including Aoki et al. (2004), Iacoviello (2002), and Elbourne (2008). Aoki et al. (2004) used a recursive VAR model to estimate the responsiveness of U.K. house prices to monetary policy, and found that after a 50 basis points interest

\footnotetext{
$\overline{{ }^{1} \text { Bernanke }}$ proposed stronger regulation and supervision aimed at problems with underwriting practices and lenders' risk management would have been a more effective and surgical approach to constraining the housing bubble than a general increase in interest rates.
} 
rate shock, the U.K. house prices would be $0.8 \%$ lower five quarters. Iacoviello (2002) estimated a structural VAR model for six European countries and found that monetary policy has a significant effect on house prices. Elbourne (2008) proposed a monetary transmission mechanism via the housing market, and used an eight-variable structural VAR model to estimate the U.K. housing market and the monetary policy transmission mechanism.

The subprime mortgage crisis caused by bubble crashes in the U.S. house market affected economies around the world, motivating many scholars to investigate the correlation between monetary policies and house prices. Certain studies have asserted that easing monetary policies may cause house price bubbles, including Shiller (2009), Yang, Wang and Cambell (2010), McDonald and Stokes (2013). Shiller (2009) recognized that the period of extreme low federal funds rates coincided with the most rapid rise in house price. Shiller also argued that loose lending standards for home mortgages also caused the increasing house prices. Yang, Wang and Campbell (2010) measured the heterogeneous effects of monetary policy on regional house prices in Sweden, and found significant regional effect of monetary policy on house price boom. McDonald and Stokes (2013) focused on the analysis of determining the extent to which monetary policy produced the house price bubble. The findings in McDonald and Stokes (2013) are consistent with the view that the interest rate policy of the Federal Reserve over the period of 2001 to 2004 was the cause of the U.S. house price bubble.

Maclennan et al. (1998, 2000) and Elbourne (2008) proposed that direct and indirect effects occur, by which monetary policy could be transmitted via the housing market. The direct effect is an income or cash flow effect, and the indirect effects are wealth and credit channel effects. The direct effect indicates that when interest rate rises, disposable income (after-housing-costs) will fall. Wealth effects mean that the increase in real house prices will give individuals more wealth; credit channel effects indicate that higher interest rates reduce housing wealth and household access to credit via lower collateral levels.

Unlike Maclennan et al. (1998, 2000), Elbourne (2008) focused on the effect of monetary policies on the economy through their influence on house prices. In this paper, we discuss the effects of monetary policies on house prices, variously categorized as liquidity, interest rates, and credit channels. Liquidity is the most rapid and direct effect of monetary supplies on house prices. Specifically, when monetary supplies are increased drastically, asset prices may rise. However, this increase does not flow into real economic activity. As numerous studies showed, excessive monetary supplies can cause surplus liquidity, which leads to asset bubbles (Congdon 2005; Gouteron, Szpiro 2005; Chung 2006). Greiber and Setzer (2007) examined the relationship between money and housing variables in the euro area and in the U.S., and found evidence for asset inflation channels. That is, liquidity fuels housing market developments.

Baks and Kramer (1999) discussed the effect of monetary liquidity on asset prices; they proposed that the increase of monetary liquidity raises the demand for a fixed supply of assets, which leads to asset price inflation. Based on the Quantity Theory of Money, Gouteron and Szpiro (2005) mentioned that excess liquidity exists when money supply substantially exceeds the volume of asset transactions, and if the money stock is too great relative to the needs of the economy, it pushes up prices. However, the results of Gouteron and Szpiro (2005) showed that liquidity does not have an across-the-board effect on the asset price. Individual asset price movements are greater than the overall change of aggregate asset prices. The work of Brueggeman, Chen, and Thobodeau (1984), Ibbotson and Seigel (1984), Hartzell, Hekman, and Miles (1987), Kuhle (1987), and Rubens, Bond and Webb (1989) have all showed that real estate provided a useful hedge against inflation. With the characteristic of inflation protection, real estate can attract more investors when monetary supplies drastically increase. As such, compared to other asset markets, greater monetary inflows to housing markets increase the likelihood of bubbles forming. Goodhart and Hofmann (2008) found evidence indicating that liquidity shocks are more important in real residential property prices during booms.

Interest rates are another variable that can affect house prices. Because real estate is a high-cost asset, people typically uses mortgage to obtain the funds to purchase houses. Therefore, interest rates have a direct impact on the cost of real estate. Elbourne (2008) proposed that demand for housing is negatively related to interest rates because interest payments represent a major part of the cost of buying a house. Mishkin (2007) suggested that the user cost of capital is an important determinant of the demand for residential capital, later finding the effects of interest changes on house price changes. Extant studies have employed interest rates as the alternative variable of monetary policies to verify 
the effect that interest rates have on house prices (Harris 1989).

In addition to the effects caused by direct monetary inflows, credit channels can also be employed to observe the effect that monetary policies have on house markets. Iacoviello and Minetti (2008) proposed that households are likely to be more strongly affected than firms via the credit channel, because households have very limited available sources for finance. Shiller (2009) and Krugman (2009) asserted that the recent bubble crashes in the U.S. housing market were caused by excessively easing lending markets. They contended that low interest rates can promote increases in house price. However, interest rates decline cannot explain the rising trend in house markets over the last nine years. Loose credit standards contributed to the housing bubble.

This study discusses the effect of liquidity, the most direct and short-term monetary effect. This work investigates monthly data and employs dynamic models capable of evaluating short-term effects. Thus, the results of this paper could measure the effect of monetary supplies on house prices within a relatively short period to evaluate monetary liquidity.

First, this study explains the correlations between monetary supplies and house price bubbles. Second, this paper adopts U.S. housing market data from January 1991 to August 2012 and uses three essential overall economic variables to classify house price fluctuations as either related to fundamentals or unrelated to fundamentals, such as bubbles. Finally, this study employs the time varying coefficient model to evaluate if a correlation does exist between house price bubbles and monetary supplies. The empirical results verify that monetary liquidity can explain irrational continuous increases in house prices. Further, by employing other proxy variables for monetary policies such as long-term and short-term interest rates, this study arrives at the finding that interest rates cannot explain the behavior of house price bubbles.

Compared with extant studies, this article attempts to answer the following questions: Does monetary liquidity affect the irrational behavior of house prices? Which among the effects of monetary policy is the primary cause of house price bubbles? When does surplus money lead to house price bubbles? Based on these research questions, the study provides a comprehensive discussion of the effects of monetary liquidity on house prices.

Compared with other studies, this article provides the following four contributions:
First, this study explains the correlation between monetary liquidity and house price bubbles before using empirical evidence for verification. Second, this study discusses and evaluates the most direct and short-term monetary effects, such as monetary liquidity. To this end, the study uses monthly data and a dynamic model capable of evaluating short-term effects to measure the effect of monetary liquidity on house price bubbles. Third, this study compares monetary liquidity to interest rates, and arrives at the finding that monetary liquidity exerts a greater influence on recent house price bubbles in the U.S. Finally, this study rationally explains when surplus money does or does not lead to house price bubbles.

The remainder of this paper is presented as follows: Section 2 builds the theoretical framework; Section 3 provides a brief explanation of empirical models; Section 4 illustrates data and reports the estimation results; and Section 5 summarizes the main conclusions of this paper.

\section{THEORETICAL FRAMEWORK FOR EMPIRICAL ANALYSIS}

Numerous studies have documented the significant correlations between monetary policies and house prices. Certain authors focused on the analysis of determining the extent to which monetary policy produced the housing price bubble. For example, McDonald and Stokes (2013) employed the S\&P/ Case-Shiller aggregate 10-city monthly housing price index, and the federal funds rate data for the period of 1987 to 2010/8. The findings in McDonald and Stokes (2013) suggest that the interest rate policy of the Federal Reserve in the period 2001to 2004 that pushed down the federal funds rate and kept it artificially low was a cause of the housing price bubble. McDonald and Stokes (2013) indicated that monetary interest rate policies can explain the formation of house price bubbles.

He et al. (2013) developed a model where housing bears a liquidity premium because it collateralizes consumption loans. Their work is partly an exercise in theory; they attempted to determine how liquidity considerations generally affect the market when housing and home-equity lending are modeled. Gali (2013) examined the impact of alternative monetary policy rules on a rational asset price bubble, through the lens of an overlapping generation model with nominal rigidities. In Gali's model, a systematic increase in interest rates in response to a growing bubble is shown to enhance fluctuations in the latter through its positive effect on bubble growth. 
Scherbina and Schlusche (2013) used interest rates to verify the effect of monetary policies on asset bubbles. In the model of Scherbina and Schlusche (2013), the asset's trading price $(P)$ can then be divided into two parts: the fundamental value (fair value) component $\left(P_{t}^{*}\right)$ and the bubble component $\left(B_{t}\right)$ :

$$
P_{t}=P_{t}^{*}+B_{t} .
$$

The fundamental value of the asset is the discounted value of expected future cash flows. Therefore, the total trading price is equal to the sum of the discounted cash flows and the present value of the future bubble component.

According to Equation (1), we can obtain the change in the total house price and divide the result into three parts:

$$
\begin{aligned}
& \Delta P_{t}=\Delta P_{t}^{*}+\Delta B_{t}=\Delta P_{t}^{*}+B_{t}-B_{t-1}= \\
& \Delta P_{t}^{*}-\left(P_{t-1}-P_{t-1}^{*}\right)+B_{t} .
\end{aligned}
$$

The growth of a positive bubble can be described as the persistence of strongly rising house prices, which makes the serial correlation of house price series:

$$
B_{t}=b \Delta P_{t-1} .
$$

The bubble component is replaced with the degree of serial correlation:

$$
\Delta P_{t}=\Delta P_{t}^{*}-\left(P_{t-1}-P_{t-1}^{*}\right)+b \Delta P_{t-1} .
$$

Equation (4) can also be extended to be a simple error correction model:

$$
\Delta P_{t}=\alpha \Delta P_{t-1}+\beta\left(P_{t-1}-P_{t-1}^{*}\right)+\gamma \Delta P_{t}^{*} .
$$

Equation (5) is similar to the model derived by Capozza et al. (1997) and discussed by Clark and Coggin (2011). The first component in equation (5) is the bubble component; $\alpha$ represents the degree of serial correlation. $\beta$ is negative, which represents the degree of mean reversion. $\gamma$ is the contemporaneous adjustment of prices to current shocks.

This study uses the error correction model to evaluate the behavior of house price bubbles. However, differing from extant studies, this study estimates the effect of monetary liquidity on house price bubbles. Previous theoretical studies have referenced the quantity theory of money to explore the effects that surplus monetary liquidity has on house price bubbles. The quantity theory of money maintains that when outputs and the velocity of money are fixed, increased monetary supplies can cause excessive money to pursue fixed asset amounts, which may cause significant rises in asset prices. Extant studies have asserted that increases in monetary supplies can lead to inflation. However, the empirical results of Gouteron and Szpiro (2005) indicated that surplus monetary liquidity only influences minority asset prices. Numerous scholars have verified that supplies in real estate markets are inflexible (Glaeser et al. 2008). Therefore, we infer that the effect of liquidity can easily occur in housing markets.

\section{EMPIRICAL MODEL}

The goal of this paper is to more completely discriminate the liquidity effect of monetary policy on house price behavior as well as housing bubble. This study references data of house price indices in the U.S., and uses the three primary economic index variables (namely, personal income, unemployment rates, and inflation rates) as fundamental factors of housing markets to measure the house price fluctuations of those that are related and unrelated to fundamentals. This study further analyzes the correlation between monetary variables and the behavior of house price bubbles.

First, to avoid the problem of spurious regression, this paper performs unit root tests for the housing price index and the three major macroeconomic variables. If the results of unit root test show that the all variables are non-stationary, then the cointegration test would be performed to test the long-run relationship between the housing price index and the three macroeconomic variables. Furthermore, if the long-run equilibrium relationship does exist, then we will further examine the error correction model described in the last section:

$$
\Delta P_{t}=\alpha \Delta P_{t-1}+\beta\left(P_{t-1}-P_{t-1}^{*}\right)+\gamma \Delta P_{t}^{*}+\varepsilon_{t},
$$

where: $P_{t}$ is the U.S. housing price index at time $t$; $P_{t}^{*}$ is the equilibrium value of housing price index determined by the three macroeconomic factors. $\alpha$ represents the degree of serial correlation (self-related behavior of housing returns) which shows the persistence of price changes and the possibility of existence of a bubble. $P_{t}-P_{t}^{*}$ shows the deviation between house price and its equilibrium value, $\beta$ can thus represent the degree of mean reversion; $\gamma$ shows the responses to information of the current period (the contemporaneous adjustment of prices).

Initially, this paper uses traditional ordinary least squares estimation to determine the error 
correction model. However, the error correction model in the equation (6) is not sufficient to illustrate the time-varying property of the fluctuations in house prices as the coefficients are constant. Therefore, this paper uses the Time Varying Coefficient approach (Engle, Watson 1987) to modify the error correction model as follows:

$$
\Delta P_{t}=\alpha_{t} \Delta P_{t-1}+\beta_{t}\left(P_{t-1}-P_{t-1}^{*}\right)+\gamma_{t} \Delta P_{t}^{*}+\varepsilon_{t} .
$$

Fluctuations in house prices were classified as related to fundamental variables, such as the mean reversion behavior $\left(\beta_{t}\right)$, the contemporaneous adjustment $\left(\gamma_{t}\right)$, and fluctuations unrelated to fundamentals, such as self-related house price behavior $\left(\alpha_{t}\right)$, that lead to housing bubbles. Obtaining the time varying coefficients enables us to estimate which effect of monetary policy produced the housing bubbles. This paper goes on to evaluate the correlation between monetary variables and the coefficients, which measures the degree of pricing bubbles.

\section{EMPIRICAL RESULTS}

\subsection{Preliminary analyses}

This study conducts empirical analysis using monthly data from $1991 \mathrm{~m} 1$ to $2012 \mathrm{~m} 8$. The data representing the performance of the U.S. housing market we collect for this study are housing price index for the entire nation. The monthly housing price index we obtain from the Office of Federal Housing Enterprise Oversight (OFHEO). This paper also selects three major macroeconomic variables, namely, personal income, unemployment rate, and consumer price index, as the fundamental factors of the housing market. For measuring different effects of monetary policy, this paper uses four variables related to monetary policy, that is, M1, M2, short-term interest rate (3 months T-bill rate), and long-term interest rate (30 year fixed mortgage rate). All the macroeconomic variables are obtained from the websites of the Bureau of Economic Analysis.

Table 1 shows the simple statistics of the variables. Figure 1 shows the historical time series of the housing price index and the three macroeconomic variables. Figure 2 shows the historical time series of the four monetary policy related variables. Table 1 shows the mean of monthly housing price index is approximately 157 . The house prices in Figure 2 indicate an obvious upward trend before 2007. Since the subprime mortgage crises occurred in the second half of 2007, the U.S. house prices began to decline significantly. The housing market stabilized eventually after 2010 . The housing price index increased significantly after 2011.

Figure 2 shows that the U.S.'s monetary policy continuously eases through, particularly during the financial crisis. However, whether such a loose monetary policy leads to the overgrowth of the housing market is a noteworthy question.

Table 1. Descriptive statistics

\begin{tabular}{|c|c|c|c|c|c|c|c|c|}
\hline Series & $\begin{array}{l}\text { House } \\
\text { price } \\
\text { (index) }\end{array}$ & $\begin{array}{l}\text { Personal } \\
\text { income } \\
\text { (billion } \\
\text { dollars) }\end{array}$ & $\begin{array}{l}\text { Unemployment } \\
\text { rate }(\%)\end{array}$ & $\begin{array}{l}\text { Consumer } \\
\text { price index }\end{array}$ & $\begin{array}{l}\text { M1 } \\
\text { (billion } \\
\text { dollars) }\end{array}$ & $\begin{array}{l}\text { M2 } \\
\text { (billion } \\
\text { dollars) }\end{array}$ & $\begin{array}{l}\text { Short-term } \\
\text { rate }(\%)\end{array}$ & $\begin{array}{l}\text { Long-term } \\
\text { rate }(\%)\end{array}$ \\
\hline Mean & 157.0931 & 9000.385 & 6.0704 & 180.0127 & 1294.777 & 5648.712 & 3.1668 & 6.7232 \\
\hline Std. Dev. & 41.9185 & 2621.669 & 1.6618 & 28.1411 & 315.0667 & 1998.797 & 2.0083 & 1.3863 \\
\hline Skewness & 0.1393 & 0.0710 & 0.8756 & 0.1541 & 1.4063 & 0.5117 & -0.3137 & -0.1380 \\
\hline Kurtosis & 1.5536 & 1.6737 & 2.7516 & 1.7827 & 4.7357 & 2.0244 & 1.6279 & 2.4629 \\
\hline $\begin{array}{l}\text { PP test } \\
\text { (Level) }\end{array}$ & $\begin{array}{l}-1.1013 \\
(0.72)\end{array}$ & $\begin{array}{l}0.2536 \\
(0.98)\end{array}$ & $\begin{array}{l}-1.0638 \\
(0.73)\end{array}$ & $\begin{array}{l}0.3933 \\
(0.98)\end{array}$ & $\begin{array}{l}4.3397 \\
(1.00)\end{array}$ & $\begin{array}{l}6.0498 \\
(1.00)\end{array}$ & $\begin{array}{l}-1.5355 \\
(0.51)\end{array}$ & $\begin{array}{l}-1.2483 \\
(0.65)\end{array}$ \\
\hline $\begin{array}{l}\text { PP test } \\
\text { (Differenced) }\end{array}$ & $\begin{array}{l}-6.9382 \\
(0.00)\end{array}$ & $\begin{array}{l}-16.3220 \\
(0.00)\end{array}$ & $\begin{array}{l}-15.7900 \\
(0.00)\end{array}$ & $\begin{array}{l}-8.2583 \\
(0.00)\end{array}$ & $\begin{array}{l}-14.5431 \\
(0.00)\end{array}$ & $\begin{array}{l}-9.8551 \\
(0.00)\end{array}$ & $\begin{array}{l}-10.1572 \\
(0.00)\end{array}$ & $\begin{array}{l}-11.9068 \\
(0.00)\end{array}$ \\
\hline $\begin{array}{l}\text { Zivot-Andrews } \\
\text { (Level) }\end{array}$ & -4.2435 & -3.2963 & -4.2866 & -5.1104 & -0.1701 & -1.7824 & -3.1543 & -4.1919 \\
\hline Break point & $2007: 10$ & 2008:10 & 2008:05 & 2006:01 & 2008:09 & 2008:09 & 2007:08 & 2008:11 \\
\hline $\begin{array}{l}\text { Zivot-Andrews } \\
\text { (Differenced) }\end{array}$ & $-7.2762^{*}$ & $-9.7948^{*}$ & $-6.2952^{*}$ & $-10.4633^{*}$ & $-7.6234^{*}$ & $-6.0941^{*}$ & $-10.0509^{*}$ & $-11.1536^{*}$ \\
\hline Break point & 2006:02 & 2008:06 & 2009:06 & 2008:08 & 2008:09 & 2003:09 & 2007:08 & 2008:09 \\
\hline
\end{tabular}

Notes: PP test and Zivot-Andrews test are adopted for testing the null hypothesis of a unit root in the series. Intercept is included in the testing equation and lag length of the unit root models are selected by Schwarz Information Criterion. Entry in parenthesis stands for the $p$-value. $1 \%$ critical values for Zivot-Andrews test is $-5.34 .{ }^{*}$ denotes significance at the $1 \%$ level. 

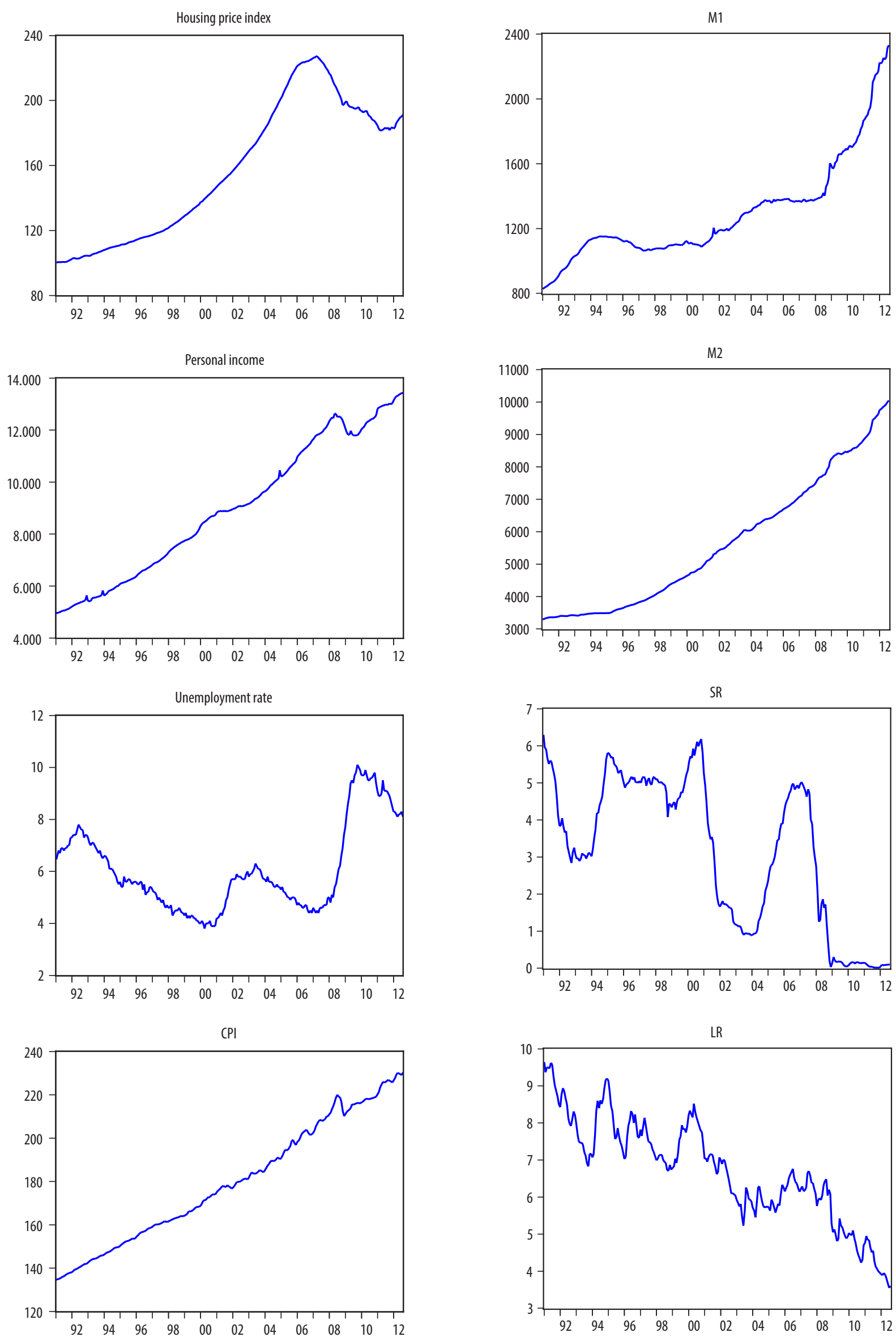

Fig. 1. Time series of house prices and macroeconomic variables

Fig. 2. Monetary policy related variables 
This study attempts to explore the correlation between monetary policy and housing bubbles by investigating whether the excess monetary liquidity leads to continuous increases in the U.S.'s housing markets, and whether the increases in the U.S.'s house prices reflects reasonable standards or the likelihood of bubbles. Table 1 also reports the outcome of tests for stationarity. The Phillips and Perron test (1988) all confirms that the variables are I(1). Considering structural changes that might be contained in the data, this study also adopts the unit root test with structural breaks proposed by Zivot and Andrews (1992). The results in Table 1 also indicate that these series are all I(1) series.

\subsection{Empirical results}

For estimating the long-run equilibrium level of house price, this paper tests the long-run relationships between the house prices and the three macroeconomic variables using traditional cointegration tests (Johansen 1988). Table 2 presents the results of Johansen's cointegration analysis. Based on trace statistics and Maximum Eigenvalue statistics, the null hypothesis of no cointegration are all rejected. The cointegration tests also indicate a cointegration vector (long-run equilibrium relation) in these variables. The results imply that the existence of a common stochastic trend, suggesting a stable long-run equilibrium relationship between the house price and these macroeconomic variables. Therefore, the fundamental factor in determining the equilibrium level of price uses the three major macroeconomic variables.

A long-term equilibrium cointegration indicates that house prices are adjusted based on the equilibrium standards. Therefore, this paper further estimates an error correction model; the estima- tion results are provided in Table 3. The fluctuating house prices indicate three behavior types. The first house price fluctuation type is self-related and can be estimated using the coefficient $\alpha$. The estimation results indicate that the housing market showed significant self-related characteristics in house price fluctuations. The second house price fluctuation type is mean reverting and can be estimated using the coefficient $\beta$. Table 3 shows house prices in the U.S. housing market did not show significant equilibrium correction. The third house price fluctuation type is estimated using the coefficient $\gamma$. Regarding the adjustment of house prices based on new information, the estimation result of the third behavior type is also not significant.

Table 3. Estimated results of ordinary least squares Model: $\Delta P_{t}=\alpha \Delta P_{t-1}+\beta\left(P_{t-1}-P_{t-1}^{*}\right)+\gamma \Delta P_{t}^{*}+\varepsilon_{t}$

\begin{tabular}{lllll}
\hline Variable & Coefficient & Std. Error & t-Statistic & $p$-value \\
\hline$\alpha$ & 0.7464 & 0.0431 & 17.3188 & 0.0000 \\
$\beta$ & -0.0013 & 0.0030 & -0.4212 & 0.6740 \\
$\gamma$ & -0.0022 & 0.0173 & -0.1301 & 0.8966 \\
\hline Adjusted & 0.4826 & Log & -258.28 & \\
R-squared & & likelihood & & \\
\hline
\end{tabular}

Note: $P_{t}$ is the U.S. housing price index at time $t ; P_{t}^{*}$ is the equilibrium value of housing price determined by the three factors; $\alpha$ stands for the degree of serial correlation which shows the persistence of price changes and the possibility of existence of a bubble; $\beta$ stands for the degree of mean reversion; $\gamma$ stands for the contemporaneous adjustment of prices.

However, Tables 2 and 3 provide inconsistent results. The results in Table 2 indicate that house prices continue to adjust toward the equilibrium value. However, the correct behavior of house prices is insignificant in Table 3. Because the model setting may contain bias, the coefficients indicate

Table 2. Cointegration test

\begin{tabular}{|c|c|c|c|c|}
\hline \multicolumn{5}{|c|}{ Unrestricted cointegration rank test (Trace) } \\
\hline Hypothesized No. of CE(s) & Eigenvalue & Trace statistic & 0.05 critical value & $p$-value \\
\hline None & 0.1816 & 67.3210 & 40.1749 & 0.0000 \\
\hline At most 1 & 0.0490 & 16.2044 & 24.2760 & 0.3650 \\
\hline At most 2 & 0.0129 & 3.3940 & 12.3209 & 0.7961 \\
\hline At most 3 & 0.0003 & 0.0886 & 4.1299 & 0.8068 \\
\hline \multicolumn{5}{|c|}{ Unrestricted cointegration rank test (Maximum Eigenvalue) } \\
\hline Hypothesized No. of CE(s) & Eigenvalue & Max-Eigen statistic & 0.05 critical value & $p$-value \\
\hline None & 0.1816 & 51.1166 & 24.1592 & 0.0000 \\
\hline At most 1 & 0.0490 & 12.8104 & 17.7973 & 0.2403 \\
\hline At most 2 & 0.0129 & 3.3054 & 11.2248 & 0.7398 \\
\hline At most 3 & 0.0003 & 0.0886 & 4.1299 & 0.8068 \\
\hline
\end{tabular}


structural changes during the evaluation period, resulting in inconsistent results. The sampling period of this study is up to 22 years. During this period, house prices form numerous bubbles and experience crashes several times, leading to structural changes in house price behavior. Therefore, we employ a dynamic model that can evaluate coefficients to obtain results with few biases.

Using a linear model which hypothesizes that the coefficients are stable to estimate the behavior of house prices with structural changes is not appropriate, this paper goes on to perform the Ramsey RESET Test. The results are provided in Table 4. RESET test is a general test for the following types of specification errors: omitted variables, incorrect functional form, and serially correlated disturbances. The results show that the linear error correction model is not an appropriate model, because the statistics both significantly reject the hypothesis that the model is appropriate.

Table 4. Structural change test

\begin{tabular}{llll}
\hline Ramsey RESET Test: & & & \\
\hline F-statistic & 8.4134 & Probability & 0.0000 \\
Log likelihood ratio & 24.6273 & Probability & 0.0000 \\
\hline
\end{tabular}

This study goes on to employ the time varying coefficient approach (Engle, Watson 1987) to evaluate changes in house prices. Figure 3 shows the three dynamic coefficients evaluated in this study. The serial correlation coefficients indicate self-related fluctuations in house prices. The selfrelated fluctuations in house prices exceeded one at two time points, which indicates that if house prices increase by $1 \%$ in the previous period, house prices will increase by more than $1 \%$ in the current period. These two time points were 1997 and 2007. The increase in house prices before 2007 has been proven as house price bubbles after crashes in house prices.

Several studies have mentioned the occurrence of house price bubbles in 1997. Shiller (2009) noted that house price bubbles in the U.S. occurred in 1997 when significant declines in federal interest rates led to significant increases in house prices. Thornton (2009) agreed that house prices have formed bubbles since 1997 because the capital interest rate of houses was eliminated in 1997. Otherwise, from 1997 to 2007, the majority of the self-related fluctuations in house prices ranged between 0.5 and 1 .

In addition, self-related house price fluctuations declined significantly in 1995 and 2008, even exhibiting negative self-related situations. In other words, when house prices increase in the current period, house prices will decrease in the following period. House price bubbles cannot be formed unless house prices continue to rise, which indicates that the probability of house price bubbles forming in these periods is relatively low.

Figure 3 shows the changes in the mean reversion coefficients indicate that house prices were drastically corrected in 1995, 2008, and 2010. During these periods, house prices exhibit the behavior of equilibrium correction significantly. Finally, this paper observes the behavior of contemporaneous adjustment in house prices and finds that house prices responded to new information in 1995 and 2008
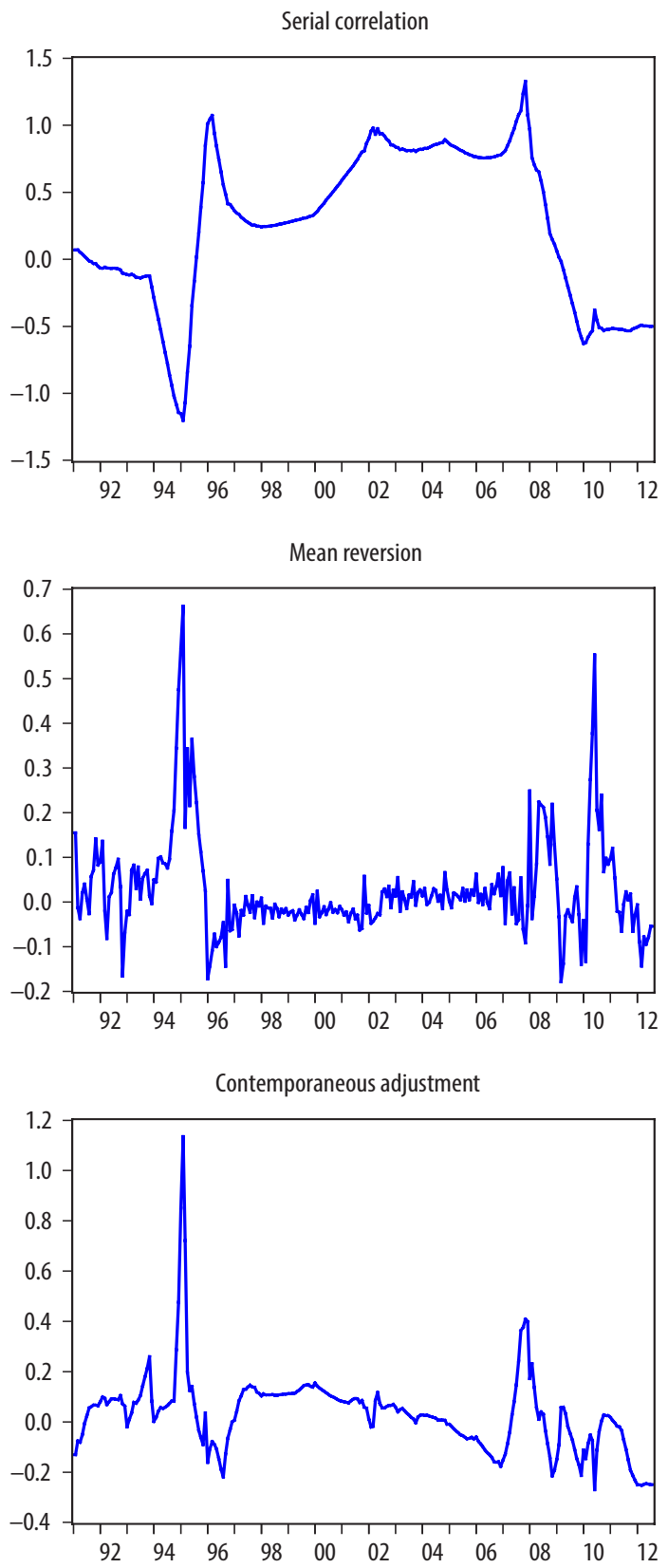

Fig. 3. Time varying coefficients 
After identifying the dynamic coefficients to describe the behavior of house prices, we can further verify whether increases in house prices unrelated to fundamentals (such as, house price bubbles) correlate to monetary policies. This paper examines whether monetary liquidity is the primary cause of house price bubbles. Table 5 shows that increases in monetary supplies (that is, increases in liquidity) can also raise self-related house price fluctuations, which then increases continuous fluctuations in house prices and the likelihood of house price bubbles forming.

The results in Table 5 verify that easing monetary policies can cause house price bubbles. Increases in monetary supply can stimulate house price fluctuations unrelated to fundamentals. These results imply that easing monetary policies causes surplus liquidity, thus resulting in irrational house price behavior. In other words, monetary liquidity is the primary cause of house price bubbles. This finding is consistent with the perspective variously propounded by Congdon (2005), Gouteron and Szpiro (2005), and Chung (2006): excessive monetary supplies are the primary cause of asset bubbles.

Table 5. Self-related behavior $\left(\alpha_{t}\right)$ and money supply (M1) Model: $\Delta \alpha_{t}=C+a_{i} \sum_{i=0}^{n} \Delta M 1_{t-i}+\varepsilon_{t}$

\begin{tabular}{lllll}
\hline Variable & Coefficient & Std. Error & t-Statistic & $p$-value \\
\hline $\mathrm{C}$ & 0.3852 & 0.0393 & 9.8099 & 0.0000 \\
$a_{0}$ & 0.0054 & 0.0026 & 2.1099 & 0.0359 \\
$a_{1}$ & 0.0055 & 0.0025 & 2.2437 & 0.0257 \\
$a_{2}$ & 0.0055 & 0.0024 & 2.2896 & 0.0229 \\
$a_{3}$ & 0.0042 & 0.0025 & 1.6977 & 0.0908 \\
\hline Adjusted & 0.1139 & Log & -200.62 & \\
R-squared & & likelihood & \\
\hline
\end{tabular}

Note: $\alpha$ stands for the degree of serial correlation which shows the persistence of price changes and the possibility of existence of a bubble; M1 is the money supply.

Table 2 shows the relationships between selfrelated fluctuations in house prices and M2, shortterm interest rates, and long-term interest rates, to determine whether other variables related to monetary policies correlate with house price bubbles. The results in Table 6 indicate that M2 has no correlation to self-related fluctuations in house prices. The liquidity of M1 is higher than that of M2. Therefore, monetary liquidity can be evaluated using M1. Comparing the results in Tables 5 and 6 , we find that the likelihood of house price bubbles forming rose with increases in monetary supplies, as shown in Table 5, was caused by liquidity.
Table 6. Self-related behavior $\left(\alpha_{t}\right)$ and other monetary variables

Model: $\Delta \alpha_{t}=C+a_{i} \sum_{i=0}^{n} \Delta M 2_{t-i}+\varepsilon_{t}$

\begin{tabular}{lllll}
\hline Variable & Coefficient & Std. Error & t-Statistic & $p$-value \\
\hline $\mathrm{C}$ & 0.1934 & 0.0564 & 3.4293 & 0.0007 \\
$a_{0}$ & -0.0008 & 0.0015 & -0.5498 & 0.5829 \\
$a_{1}$ & -0.0008 & 0.0015 & -0.4906 & 0.6241 \\
$a_{2}$ & -0.0006 & 0.0015 & -0.3865 & 0.6994 \\
$a_{3}$ & -0.0007 & 0.0015 & -0.4895 & 0.6249 \\
\hline Adjusted & 0.0115 & Log & -214.13 & \\
R-squared & & likelihood \\
\hline
\end{tabular}

Model: $\Delta \alpha_{t}=C+a_{i} \sum_{i=0}^{n} \Delta S r_{t-i}+\varepsilon_{t}$

\begin{tabular}{lllll}
\hline Variable & Coefficient & Std. Error & t-Statistic & $p$-value \\
\hline $\mathrm{C}$ & 0.2521 & 0.0354 & 7.1285 & 0.0000 \\
$a_{0}$ & 0.2242 & 0.2035 & 1.1017 & 0.2716 \\
$a_{1}$ & 0.1714 & 0.2175 & 0.7881 & 0.4314 \\
$a_{2}$ & 0.1562 & 0.2181 & 0.7162 & 0.4745 \\
$a_{3}$ & 0.1588 & 0.2052 & 0.7738 & 0.4398 \\
\hline Adjusted & 0.0336 & Log & -211.74 \\
R-squared & & likelihood \\
\hline
\end{tabular}

Model: $\Delta \alpha_{t}=C+a_{i} \sum_{i=0}^{n} \Delta L r_{t-i}+\varepsilon_{t}$

\begin{tabular}{lllll}
\hline Variable & Coefficient & Std. Error & t-Statistic & $p$-value \\
\hline $\mathrm{C}$ & 0.2818 & 0.0359 & 7.8420 & 0.0000 \\
$a_{0}$ & -0.1318 & 0.1884 & -0.6997 & 0.4848 \\
$a_{1}$ & -0.1254 & 0.1998 & -0.6278 & 0.5307 \\
$a_{2}$ & -0.1449 & 0.2002 & -0.7238 & 0.4699 \\
$a_{3}$ & -0.1834 & 0.1893 & -0.9689 & 0.3335 \\
\hline Adjusted & 0.0149 & Log & -214.19 & \\
R-squared & & likelihood & \\
\hline
\end{tabular}

Note: $\alpha$ stands for the degree of serial correlation which shows the persistence of price changes and the possibility of existence of a bubble; M2 is the money supply; $\mathrm{Sr}$ is the short-term interest rate; $\mathrm{Lr}$ is the long-term interest rate.

In Table 6, neither short-term nor long-term interest rates can explain the self-related fluctuations in house prices. This conclusion confirms that easing monetary policies cannot lead to irrational house price behaviors via interest rates and further verified that monetary liquidity can affect house price bubbles. However, previous studies, such as McDonald and Stokes (2013), showed that monetary interest rate policies can explain the formation of house price bubbles. By exploring this dynamic relationship, this study finds that easing monetary policies may cause housing bubbles through the liquidity effect. These findings appear inconsistent with the interest rate effect proposed by McDonald and Stokes (2013). 
Table 7 shows the correlations between the two coefficients describing the fluctuations in house prices and M1. The results in Table 7 indicate that the M1 fluctuations had no correlation with the coefficient of mean reversion, which indicates that monetary supplies do not affect the fluctuations of house prices related to fundamentals. Table 7 also shows that M1 fluctuations had no correlation with the contemporaneous adjustment of house prices. Therefore, the results of this study confirm that surplus monetary liquidity can lead to continuous increases in house prices, but will not affect the correlation between house prices and other variables. This conclusion can explain when surplus money causes house price bubbles, and why continuous increases in money occasionally do not cause house price bubbles. Surplus liquidity led by easing monetary policies can increase the likelihood of house price bubbles forming. However, downward adjustments with the overall variables in house prices may not form obvious house price bubbles.

Table 7. Mean reversion, contemporaneous and M1

Model: $\Delta \beta_{t}=C+a_{i} \sum_{i=0}^{n} \Delta M 1_{t-i}+\varepsilon_{t}$

\begin{tabular}{lllll}
\hline Variable & Coefficient & Std. Error & t-Statistic & $p$-value \\
\hline $\mathrm{C}$ & 0.0241 & 0.0082 & 2.9441 & 0.0035 \\
$a_{0}$ & -0.0001 & 0.0005 & -0.1881 & 0.8510 \\
$a_{1}$ & -0.0001 & 0.0005 & -0.2404 & 0.8102 \\
$a_{2}$ & -0.0002 & 0.0005 & -0.4480 & 0.6546 \\
$a_{3}$ & -0.0005 & 0.0005 & -1.0624 & 0.2891 \\
\hline Adjusted & 0.0088 & Log & 200.74 & \\
R-squared & & likelihood & & \\
\hline
\end{tabular}

Model: $\Delta \gamma_{t}=C+a_{i} \sum_{i=0}^{n} \Delta M 1_{t-i}+\varepsilon_{t}$

\begin{tabular}{lllll}
\hline Variable & Coefficient & Std. Error & t-Statistic & $p$-value \\
\hline $\mathrm{C}$ & 0.0508 & 0.0111 & 4.5658 & 0.0000 \\
$a_{0}$ & 0.0007 & 0.0007 & 0.9637 & 0.3361 \\
$a_{1}$ & 0.0007 & 0.0007 & 0.9347 & 0.3509 \\
$a_{2}$ & 0.0008 & 0.0007 & 1.2329 & 0.2188 \\
$a_{3}$ & 0.0007 & 0.0007 & 1.0419 & 0.2985 \\
Adjusted & 0.0314 & Log & 122.37 & \\
R-squared & & likelihood & & \\
\hline
\end{tabular}

Note: $\beta$ stands for the degree of mean reversion; $\gamma$ stands for the contemporaneous adjustment of prices; M1 is the money supply.

\section{CONCLUSIONS}

This study explains the correlation between monetary liquidity and house price bubbles using both the theoretical and empirical model analyses. By classifying fluctuations in house prices as fluctuations related to fundamentals and bubbles, this work then employs an error correction model to verify that monetary surplus liquidity can increase the likelihood of housing bubbles.

This study references data of house price indices in the U.S. from January 1991 to August 2012 and uses the three variables of primary economic indices, namely, personal income, unemployment rates, and consumer price indices. Further, this work evaluates the correlation between house prices and the three essential macroeconomic variables to identify the house price fluctuations related to fundamentals (the mean reversion behavior and responses to information of the current period) and those unrelated to fundamentals (selfrelated behavior).

This paper uses the time-varying coefficient model to identify the dynamic coefficients that describe house price fluctuations. The results indicate that a rise in M1 may increase self-related fluctuations in house prices. In other words, continuous fluctuations in house prices and the likelihood of the formation of house price bubbles are increased. However, M2 cannot explain the continuous fluctuations in house prices. Considering that liquidity of M1 is higher than that of M2, and the liquidity fluctuations of M1 are relatively significant, we easily observe the effect of surplus liquidity on house price bubbles in the model with the M1 as proxy variable. This result suggests that monetary liquidity is the primary cause of house price bubbles.

The results of this study indicate that neither short-term nor long-term interest rates can explain the irrational continuous increases in house prices. This finding confirms that monetary interest rates are not the primary cause of house price bubbles. Finally, regarding the correlation between house prices and different variables, the results of the evaluation verify that surplus monetary liquidity can influence only the continuous fluctuations in house prices, whereas monetary supplies do not affect the fluctuations of house prices related to fundamentals. This study proposes a rational explanation for scenarios when surplus money does or does not lead to house price bubbles. Surplus liquidity caused by the easing of monetary policies can increase the likelihood of house price bubble formation. However, fluctuations in house prices can also be affected by other macroeconomic variables.

The theoretical and empirical results of this study confirm the correlation between monetary 
liquidity and house price bubbles. Therefore, the study provides evidence showing that easing monetary policies may cause housing bubbles via the liquidity effect. Unlike previous studies focusing on how lower interest rates might cause asset bubbles, the results of this paper confirm that monetary interest rates are not the primary cause of house price bubbles, suggesting that the Fed should consider overall economic conditions in implementing monetary policies and in evaluating the potential influence of surplus money supply on house price bubbles.

\section{ACKNOWLEDGEMENTS}

Funding from the National Science Council of Taiwan under Project No. NSC 102-2628-H-390-001 has enabled the continuation of this research and the dissemination of these results. I am very grateful to the two anonymous referees and the editor for their helpful comments and suggestions.

\section{REFERENCE}

Aoki, K.; Proudman, J.; Vlieghe, G. 2004. House prices, consumption, and monetary policy: a financial accelerator approach, Journal of Financial Intermediation 13(4): 414-435. http://dx.doi.org/10.1016/j. jfi.2004.06.003

Baks, K.; Kramer, C. F. 1999. Global liquidity and asset prices: measurement, implications, and spillovers, IMF Working Papers 99/168. International Monetary Fund, New York.

Bernanke, B. S. 2010. Monetary policy and the housing bubble, speech at the annual meeting of the American Economic Association, 3 January 2010, Atlanta, Georgia.

Brueggeman, W. B.; Chen, A. H.; Thibodeau, T. G. 1984. Real estate investment funds: performance and portfolio considerations, Real Estate Economics 12(3): 333-354. http://dx.doi.org/10.1111/1540-6229.00326

Capozza, D. R.; Mack, C.; Mayer, C. J. 1997. The dynamic structure of housing markets, Working Paper. University of Michigan Business School.

Chung, K. 2006. Asset prices and monetary liquidity in Korea, Working Papers. The Bank of Korea.

Clark, S. P.; Coggin, T. D. 2011. Was there a U.S. house price bubble? An econometric analysis using national and regional panel data, Quarterly Review of Economics and Finance 51: 189-200. http://dx.doi. org/10.1016/j.qref.2010.12.001

Congdon, T. 2005. Money and asset prices in boom and bust. London: The Institute of Economic Affairs.

Elbourne, A. 2008. The UK housing market and the monetary policy transmission mechanism: an SVAR approach, Journal of Housing Economics 17: 65-87 http://dx.doi.org/10.1016/j.jhe.2007.09.002
Engle, R. F.; Watson, M. 1987. The Kalman filter: applications to forecasting and rational-expectations models, Advances in Econometrics, Fifth World Congress. Cambridge University Press. http://dx.doi. org/10.1017/CCOL0521344301.007

Gali, J. 2013. Monetary policy and rational asset price bubbles, NBER Working Paper No.18806. National Bureau of Economic Research.

Greiber, C.; Setzer, R. 2007. Money and housing: evidence for the euro area and the US (No. 2007, 12). Discussion Paper, Series 1: Economic Studies No. 12/2007. Deutsche Bundesbank.

Goodhart, C.; Hofmann, B. 2008. House prices, money, credit, and the macro-economy, Oxford Review of Economic Policy 24(1): 180-205. http://dx.doi. org/10.1093/oxrep/grn009

Glaeser, E. L.; Gyourko, J. E.; Saiz, A. 2008. Housing supply and housing bubbles, Harvard Institute of Economic Research Discussion Paper No. 2158. Available at: http://ssrn.com/abstract=1169182

Gouteron, S.; Szpiro, D. 2005. Excess monetary liquidity and asset prices, Working Paper No. NER-E 131. Banque de France (Notes des Etudes et de Recherche, Banque de France).

Harris, J. C. 1989. The effect of real rates of interest on housing prices, Journal of Real Estate Finance and Economics 2: 47-60. http://dx.doi.org/10.1007/ BF00161716

Hartzell, D.; Hekman, J. S.; Miles, M. E. 1987. Real estate returns and inflation, Real Estate Economics 15(1): 617-637. http://dx.doi.org/10.1111/15406229.00407

He, C.; Wright, R.; Zhu, Y. 2013. Housing and liquidity. The Ohio State University, Unpublished manuscript.

Iacoviello, M. 2002. House prices and business cycles in Europe: a VAR Analysis, Boston College Working Paper 540. Boston College.

Iacoviello, M. 2005. House prices, borrowing constraints and monetary policy in the business cycle, American Economic Review 95(3): 739-764. http://dx.doi. org/10.1257/0002828054201477

Iacoviello, M.; Minetti, R. 2008. The credit channel of monetary policy: evidence from the housing market, Journal of Macroeconomics 30(1): 69-96. http:// dx.doi.org/10.1016/j.jmacro.2006.12.001

Ibbotson, R. G.; Siegel, L. B. 1984. Real estate returns: a comparison with other investments, Real Estate Economics 12(3): 219-242. http://dx.doi. org/10.1111/1540-6229.00320

Johansen, S. 1988. Statistical analysis of cointegration vectors, Journal of Economic Dynamics and Control 12: 231-254. http://dx.doi.org/10.1016/01651889(88)90041-3

Krugman, P. 2009. The return of depression economics. New York: Norton.

Kuhle, J. 1987. Portfolio diversification and returns benefits - common stock vs. real estate investment trusts, Journal of Real Estate Research 2(2): 1-9.

Maclennan, D.; Muellbauer, J.; Stephens, M. 2000. Asymmetries in housing and financial market institutions and EMU, in Jenkinson, T. (Ed.). Readings in macroeconomics. 2 ed. Oxford: Oxford University Press, 74-98. 
Maclennan, D.; Muellbauer, J.; Stephens, M. 1998. Asymmetries in housing and financial market institutions and EMU, Oxford Review of Economic Policy 14(3): 54-80. http://dx.doi.org/10.1093/oxrep/14.3.54

McDonald, J.; Stokes, H. 2013. Monetary policy and the housing bubble, Journal of Real Estate Finance and Economics 46(3): 437-451. http://dx.doi.org/10.1007/ s11146-011-9329-9

Mishkin, F. S. 2007. Housing and the monetary transmission mechanism, Working Paper 13518. National Bureau of Economic Research.

Phillips, P. C.; Perron, P. 1988. Testing for a unit root in time series regression, Biometrika 75(2): 335-346 http://dx.doi.org/10.1093/biomet/75.2.335

Rubens, J.; Bond, M.; Webb, J. 1989. The inflationhedging effectiveness of real estate, Journal of Real Estate Research 4: 45-56.

Scherbina, A.; Schlusche, B. 2013. Asset price bubbles: a survey, Quantitative Finance 14(4): 589-604. http:// dx.doi.org/10.1080/14697688.2012.755266
Shiller, R. J. 2009. The subprime solution: how today's global financial crisis happened, and what to do about it. Princeton: Princeton University Press.

Taylor, J. B. 2007. Housing and monetary policy, NBER Working Paper Series 13682, December. Cambridge, Mass: National Bureau of Economic Research. Available at: www.nber.org/papers/w13682.pdf

Thornton, M. 2009. The economics of housing bubbles, in Holcombe, R.; Powell, B. (Eds.). Housing America: building out of a crisis. New Brunswick: Transactions, 237-262.

Yang, Z.; Wang, S.; Campbell, R. 2010. Monetary policy and regional price boom in Sweden, Journal of Policy Modeling 32(6): 865-879. http://dx.doi.org/10.1016/j. jpolmod.2010.06.004

Zivot, E.; Andrews, D. W. K. 1992. Further evidence on the Great Crash, the oil-price shock, and the unitroot hypothesis, Journal of Business and Economic Statistics 10(3): 251-270. http://dx.doi.org/10.1080/0 7350015.1992 .10509904 